\title{
Peningkatan Hasil Belajar Matematika Materi Penjumlahan dan Pengurangan Bilangan Bulat Melalui Media Pohon Matematika
}

\author{
Wagimin \\ Sekolah Dasar Negeri 1 Tanggaran \\ Email: wagimin438@gmail.com
}

\begin{abstract}
Abstrak: Proses pembelajaran akan berlangsung secara baik apabila guru mampu menciptakan kondisi belajar yang dapat mengembangkan pola pikir siswa dan menjadikan belajar menjadi bermakna. Berdasarkan pengamatan di kelas VSDN 1 Tanggaran, pada pembelajaran materi penjumlahan dan pengurangan bilangan bulat guru tidak menggunakan media dalam menyampaikan materi, guru masih terlalu banyak menggunakan metode ceramah. Hasil tes menunjukkan bahwa 12 siswa $(60 \%)$ dari 20 siswa nilainya tidak mencapai KKM. Rumusan masalah dalam penelitian ini adalah "Bagaimana peningkatan hasil belajar matematika materi penjumlahan dan pengurangan bilangan bulat melalui Media Pohon Matematika pada siswa kelas V SD Negeri 1 TanggaranKecamatan Pule Kabupaten Trenggalek
\end{abstract}

Tersedia Online di

http://journal.unublitar.ac.id/pendidikan /index.php/Riset_Konseptual

Sejarah Artikel

Diterima pada : 01-10-2020

Disetuji pada : $31-10-2020$

Dipublikasikan pada : 31-10-2020

Kata Kunci:

hasil belajar matematika, penjumlahan dan pengurangan bilangan bulat, media pohon matematika

DOI:

http://doi.org/10.28926/riset_konseptual.v4i4.2 99 Semester 1 Tahun Pelajaran 2018/2019?”. Adapun tujuan penelitian untuk mendapatkan gambaran objektif tentang peningkatan hasil belajar matematika materi penjumlahan dan pengurangan bilangan bulat melalui Media Pohon Matematika pada siswa kelas V SD Negeri 1 TanggaranKecamatan Pule Kabupaten Trenggalek Semester 1 Tahun Pelajaran 2018/2019. Hasil penelitian menunjukkan bahwa ketuntasan belajar pada pra siklus, siklus I, dan siklus II juga meningkat yaitu 40\% (tidak tuntas), 55\% (tdak tuntas) dan 75\% (tuntas).

\section{PENDAHULUAN}

Salah satu tujuan pendidikan adalah menghasilkan perubahan-perubahan positif dalam diri seseorang. Pendidikan dapat diperoleh di manapun seseorang berada, salah satunya di sekolah. Di sekolah dilaksanakan serangkaian kegiatan belajar mengajar yang bertujuan menghasilkan perubahan-perubahan positif di dalam diri siswa yang dapat dilakukan melalui pembelajaran.

Berdasarkan observasi di SD Negeri 1 Tanggaran Kecamatan Pule Kabupaten Trenggalek diketahui bahwa hasil belajar siswa kelas V SD Negeri 1 Tanggaran mata pelajaran Matematika pada materi penjumlahan dan pengurangan bilangan bulat tergolong rendah. Hal ini dapat dilihat dari banyaknya siswa yang belum berhasil dalam ulangan harian. Hasil ulangan harian tersebut menunjukkan bahwa 12 siswa dari 20 siswa $(60 \%)$ nilainya tidak mencapai KKM. Rata-rata nilai yang dicapai siswa adalah 59 padahal KKM mata pelajaran Matematika kelas $V$ yang ditentukan oleh SD Negeri 1 Tanggaran adalah 65, dan nilai yang diperoleh siswa yang belum berhasil jauh dari KKM yang telah ditetapkan. Berdasarkan refleksi yang dilakukan, teridentifikasi masalah bahwa (1) siswa kelas V SDN 1 Tanggaran kurang dapat menjumlahkan dan mengurangkan bilangan bulat; dan (2) siswa kelas $\mathrm{V}$ SDN 1 Tanggaran kurang memperhatikan penjelasan guru.

Berdasarkan pengamatan yang telah dilakukan peneliti, penyebab belum berhasilnya pembelajaran siswa kelas V SDN 1 Tanggaran pada materi penjumlahan dan pengurangan bilangan bulat karena dalam kegiatan pembelajaran guru tidak menggunakan media dalam menyampaikan materi kepada siswa. Di samping itu, guru 
lebih banyak menggunakan metode ceramah yaitu dengan memberikan contoh-contoh soal tentang penjumlahan dan pengurangan bilangan bulat, serta cara menyelesaikannya. Kemudian guru meminta siswa untuk mengerjakan soal-soal tentang penjumlahan dan pengurangan bilangan cacah yang ada di buku paket. Siswa cenderung menghafal hasil dari penjumlahan. Sebagai contoh, $55+20=75$. Akan tetapi, apabila menemui soal $-76-(-35)=\ldots$, sebagian besar siswa tidak dapat menyelesaikan soal tersebut. Dampak dari pembelajaran tersebut hasil belajar yang dicapai siswa masih banyak yang berada di bawah KKM.

Berdasarkan hasil observasi di atas, maka perlu penyelesaian dengan menggunakan media pohon matematika. Pembelajaran dengan media pohon matematika merupakan balikan dari pembelajaran yang biasa dilakukan di kelas, terutama dalam latihan-latihan soal yang diberikan. Pada pembelajaran dengan pohon matematika, guru menyajikan pohon sebagai pokok bahasan, ranting sebagai jawaban atau masalah. Jika ranting berisi jawaban, maka siswa diminta mengkonstruksi soal di daunnya. Jika ranting berisi masalah (open ended), maka siswa mencari semua jawaban sebagai daunnya.

Subanji $(128,2011)$ menyatakan bahwa pohon matematika merupakan suatu media yang dapat digunakan untuk mengembangkan penalaran siswa. Pembelajaran dengan pohon matematika merupakan balikan dari pembelajaran yang biasa dilakukan di kelas, terutama dalam latihan-latihan soal yang diberikan. Subanji $(129,2011)$ juga menyatakan bahwa dalam pembelajaran dengan pohon matematika, guru menyajikan pohon sebagai pokok bahasan, ranting sebagai jawaban atau masalah. Jika ranting berisi jawaban, maka siswa diminta mengkonstruksi soal di daunnya. Jika ranting berisi masalah (open ended), maka siswa mencari semua jawaban sebagai daunnya.

Adapun bahan-bahan yang digunakan untuk membuat media pohon matematika dalam penelitian ini adalah (1) kertas kuarto, (2) kertas folio berwarna hijau dan coklat. Sedangkan alat yang digunakan adalah pensil, gunting, dan lem. Langkahlangkah pembuatan media pohon matematika adalah sebagai berikut: 1) Menggambar batang pohon disertai ranting pada kertas folio berwarna coklat dengan menggunakan pensil. 2) Menggunting batang pohon yang telah dibuat pada langkah 1. 3) Menempelkan batang pohon pada kertas kuarto. 4) Menuliskan permasalahan yang akan diselesaikan siswa pada ranting pohon. 5) Menggambar bentuk daun pada kertas folio berwarna hijau. 6) Menggunting bentuk daun yang telah dibuat pada langkah 5.

Adapun cara penggunaan media pohon matematika ini adalah sebagai berikut: 1) Disajikan media pohon matematika yang telah dibuat seperti pada langkah-langkah di atas (ranting sudah berisi suatu permasalahan yang akan diselesaikan siswa). 2) Siswa diminta membuat daun pohon matematika dengan cara menuliskan jawaban permasalahan pada daun yang disediakan. 3) Siswa diminta menempelkan daun pada ranting pohon matematika.

Pada penelitian ini, pohon matematika disajikan sebagai pokok bahasan (materi) yaitu bilangan bulat. Ranting sebagai masalah tentang penjumlahan dan pengurangan bilangan bulat. Daun sebagai jawaban dari masalah tentang penjumlahan dan pengurangan bilangan bulat. Adapun gambar pohon matematika tersebut dapat dilihat pada Gambar 2.1 


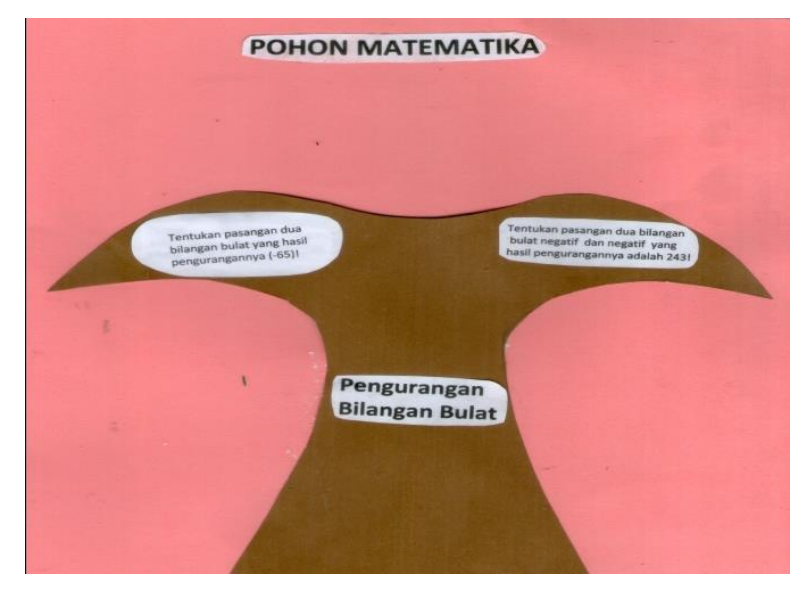

\section{Gambar 2.1 Media Pohon Matematika}

Langkah-langkah pembelajaran dengan media pohon matematika ada 3, yaitu (1) penyajian materi, (2) penumbuhan pohon matematika, dan (3) evaluasi. Adapun langkah-langkah pembelajaran dengan media pohon matematika yang akan diterapkan dalam penelitian ini adalah sebagai berikut:

\section{METODE}

Penelitian ini adalah Penelitian Tindakan Kelas, adapun tahap penelitian tindakan kelas berupa suatu siklus yang meliputi (1) kegiatan perencanaan, (2) pelaksanaan tindakan, (3) pengamatan, dan (4) refleksi, yang membentuk siklus demi siklus sampai mencapai kriteria yang ditetapkan. Dari siklus ini diharapkan dapat diperoleh data yang dikumpulkan sebagai jawaban dari permasalahan penelitian. Perencanaan perbaikan dirumuskan dengan memperhatikan proses maupun hasil yang diperoleh pada siklus I, kemudian dilanjutkan pada tahapan pelaksanaan, observasi dan refleksi. Perbaikan pembelajaran matematika ini dilaksanakan dalam dua siklus sebagai berikut.

\section{Siklus I}

Perencanaan Tindakan I. Tindakan yang direncanakan pada siklus I adalah pembelajaran dengan media pohon matematika. Adapun hal-hal yang dilakukan pada tahap ini sebagai berikut: 1) Menyusun rencana pelaksanaan pembelajaran (RPP) silkus I yang nantinya akan digunakan dalam proses pembelajaran dan soal tes untuk evaluasi. 2) Mempersiapkan nilai siswa sebelum diberikan tindakan yang nantinya digunakan sebagai pembanding hasil belajar siswa dengan setelah diberikan tindakan. 3) Merencanakan pembagian kelompok 4) Mempersiapkan media pohon matematika yang akan digunakan 5) Membuat lembar observasi (siswa dan guru)

Pelaksanaan Tindakan I. Pada tahap pelaksanaan siklus I, peneliti dibantu oleh seorang teman sejawat yang melakukan observasi pembelajaran dengan menggunakan media pohon matematika sebagaimana direncanakan dalam RPP, dengan langkah-langkah sebagai berikut: 1) Peneliti melakukan tanya jawab dengan siswa tentang cara menjumlahkan dan mengurangkan bilangan bulat 2) Peneliti mengelompokkan siswa menjadi 10 kelompok kecil secara heterogen. 3) Peneliti meminta siswa berdiskusi untuk menumbuhkan daun pada media pohon matematika berdasarkan petunjuk di LKS. 4) Peneliti membimbing siswa untuk memeriksa kebenaran jawaban yang dituliskan pada daun pohon matematika. 5) Peneliti meminta siswa mengerjakan soal evaluasi secara perorangan mengenai penjumlahan dan pengurangan bilangan bulat.

Observasi I. Observasi I dilaksanakan bersamaan dengan pelaksanaan tindakan. Observasi ini bertujuan untuk mengamati aktivitas guru dan aktivitas siswa. Aktivitas 
siswa diamati oleh peneliti, sedangkan aktivitas guru diobservasi oleh satu orang teman sejawat. Observasi ini menggunakan lembar observasi yang telah disiapkan untuk mengamati kejadian-kejadian selama proses pembelajaran dengan media pohon matematika.

Refleksi I. Pada tahap ini peneliti menganalisis data yang diperoleh pada tindakan I. Setelah data dianalisis, akan diperoleh temuan-temuan yang berkaitan dengan tindakan pada siklus I. Berdasarkan refleksi siklus I, akan dilakukan perbaikan terhadap hal-hal yang belum dicapai pada siklus I. Hal-hal yang belum tercapai tersebut akan diperbaiki pada siklus II.

1. Siklus II

Tahap-tahap yang dilakukan pada siklus II secara garis besar sama dengan tahap-tahap pada siklus I. Tahap-tahap kegiatan pada siklus II merupakan perbaikan dari siklus I.

Penelitian ini dilakukan pada bulan September sampai dengan Oktober pada tahun pelajaran 2018/2019. Adapun jadwal pelaksanaan perbaikan pembelajaran adalah sebagai berikut:

Tabel 3.1 Jadwal Penelitian Tindakan Kelas

\begin{tabular}{|c|l|c|l|}
\hline No. & \multicolumn{1}{|c|}{ Hari/Tanggal } & Siklus & \multicolumn{1}{|c|}{ Materi } \\
\hline 1. & $\begin{array}{l}\text { Jum'at, 9 } \\
\text { September 2016 }\end{array}$ & I & $\begin{array}{l}\text { Penjumlahan bilangan bulat positif dengan } \\
\text { positif dan penjumlahan bilangan bulat } \\
\text { positif dengan negatif }\end{array}$ \\
\hline 2. & $\begin{array}{l}\text { Sabtu, 10 } \\
\text { September 2016 }\end{array}$ & I & $\begin{array}{l}\text { Penjumlahan bilangan bulat negatif dengan } \\
\text { positif dan penjumlahan bilangan bulat } \\
\text { negatif dengan negatif }\end{array}$ \\
\hline 3. & $\begin{array}{l}\text { Jum'at, } \\
\text { September 2016 }\end{array}$ & II & $\begin{array}{l}\text { Pengurangan bilangan bulat positif dengan } \\
\text { positif dan pengurangan bilangan bulat } \\
\text { positif dengan negatif }\end{array}$ \\
\hline 4. & $\begin{array}{l}\text { Sabtu, } \\
\text { September 2016 }\end{array}$ & II & $\begin{array}{l}\text { Pengurangan bilangan bulat negatif dengan } \\
\text { positif dan pengurangan bilangan bulat } \\
\text { negatif dengan negatif }\end{array}$ \\
\hline
\end{tabular}

\section{Subjek Penelitian.}

Subjek penelitian ini adalah siswa-siswi kelas V SD Negeri 1 Tanggaran Kecamatan Pule Kabupaten Trenggalek Semester 1 Tahun Pelajaran 2018/2019. SD Negeri 1 Tanggaran beralamat di RT 09 RW 01, Desa Tanggaran, Kecamatan Pule. Subjek penelitian ini adalah 20 siswa dengan kemampuan heterogen yang terdiri atas 10 siswa laki-laki dan 10 siswa perempuan. Penelitian ini dilakukan pada mata pelajaran Matematika, standar kompetensi 1 yaitu melakukan operasi hitung bilangan bulat dalam pemecahan masalah. Peneliti memilih subjek tersebut karena hasil belajar matematika materi penjumlahan dan pengurangan bilangan bulat pada siswa subjek penelitian tergolong rendah.

\section{Instrumen Penelitian}

Instrumen penelitian merupakan alat yang digunakan untuk memperoleh data yang diperlukan dalam penelitian. Instrumen yang digunakan dalam penelitian ini sebagai berikut:

1) Instrumen Tes. Instrumen tes pada penelitian ini berupa soal tes tulis yang berbentuk soal uraian. Soal tersebut terdiri dari empat soal tentang penjumlahan dan pengurangan bilangan cacah.

2) Instrumen Nontes. Instrumen nontes pada penelitian ini berupa lembar observasi yang terdiri atas lembar observasi aktivitas siswa dan lembar observasi aktifitas guru.

Lembar Observasi Aktivitas Siswa 
Lembar observasi aktivitas siswa digunakan untuk mengetahui keaktifan siswa pada kegiatan diskusi.

Lembar Observasi Aktivitas Guru. Lembar observasi aktivitas guru digunakan untuk memperoleh data tentang aktivitas guru dalam mengelola pembelajaran dengan menerapkan media pohon matematika.

\section{Teknik pengumpulan Data}

Tes. Tes dilakukan di akhir pembelajaran pada siklus I dan siklus II. Tes yang dilakukann berupa tes tulis tentang penjumlahan dan pengurangan bilangan bulat. Tes tersebut digunakan peneliti untuk mengukur hasil belajar matematika materi penjumlahan dan pengurangan bilangan bulat pada siswa kelas V SD Negeri 1 Tanggaran.

Observasi. Penelitian ini menggunakan observasi secara langsung. Observasi langsung yang dimaksud yaitu peneliti melihat dan mengamati sendiri kegiatan pembelajaran yang dilakukan selama kegiatan belajar mengajar. Observasi ini bertujuan untuk mengamati aktivitas siswa dan guru saat kegiatan pembelajaran sedang berlangsung. Observasi akan dilakukan oleh peneliti yang dibantu oleh satu orang teman sejawat.

Dokumentasi. Dokumentasi dalam penelitian ini bertujuan untuk mendokumentasikan kegiatan pembelajaran yang berlangsung. Dokumentasi akan dilakukan oleh seorang teman sejawat.

\section{Teknik Analisis Data}

Analisis data merupakan dasar untuk menentukan keberhasilan pemberian tindakan yang telah dilakukan dan dasar untuk merencanakan tindakan selanjutnya apabila pemberian tindakan sebelumnya tidak berhasil. Adapun analisis hasil belajar matematika adalah sebagai berikut:

Nilai Tes. Peneliti menghitung nilai tes siswa, baik nilai pengamatan kegiatan diskusi maupun nilai tes tulis dengan rumus sebagai berikut:

$$
\text { Nilai siswa }=\frac{\sum \text { skor yang diperoleh }}{\sum \text { skor maksimal }} \times 100
$$

Nilai yang diperoleh dari rumus di atas kemudian diinterpretasikan ke dalam rentangan interpretasi data sebagai berikut:

Tabel 3.2. Standar Kualitas Pencapaian Keberhasilan

\begin{tabular}{|c|c|}
\hline Skor Penilaian & Kategori \\
\hline $65-100$ & Tuntas \\
\hline $0-64$ & Belum Tuntas \\
\hline
\end{tabular}

Rata-rata Nilai Tes

Peneliti menghitung rata-rata nilai tes dengan rumus sebagai berikut:

$$
\text { Rata }- \text { rata }=\frac{\sum \text { nilai tes }}{\sum \text { siswa subjek penelitian }} \times 100
$$

Ketuntasan Belajar

Peneliti melakukan perhitungan untuk mengukur persentase ketuntasan belajar siswa dengan menggunakan rumus sebagai berikut:

persentase ketuntasan $=\frac{\sum \text { siswa yang tuntas }}{\sum \text { siswa subjek penelitian }} \times 100 \%$

Adapun analisis data hasil belajar matematika adalah sebagai berikut:

Ketuntasan siswa dianggap berhasil apabila siswa telah mencapai nilai minmal yaitu 65 . 
Kelas dikatakan berhasil jika $65 \%$ dari jumlah semua siswa kelas V SD Negeri 1 Tanggaran memperoleh ketuntasan berdasarkan KKM SD Negeri 1 Tanggaran tahun pelajaran 2016/ 2017 yaitu 65.

\section{Paparan Prasiklus}

\section{HASIL DAN PEMBAHASAN}

Pembelajaran pada prasiklus menggunakan metode tanya jawab dan ekspositori. Peneliti membuka pembelajaran dengan salam, kemudian meminta ketua kelas memimpin doa dan mengecek kehadiran siswa. Selanjutnya, siswa diingatkan kembali tentang materi pada pertemuan sebelumnya yaitu tentang bilangan bulat. Kemudian peneliti memberitahukan materi yang akan dibahas yaitu membaca dan menulis bilangan bulat. Peneliti memulai kegiatan inti dengan memberikan contoh soal tentang menulis lambang bilangan dan nama bilangan bulat. Kemudian guru menjelaskan cara menyelesaikan soal tersebut. Selanjutnya guru memberikan beberapa soal pada buku paket dan meminta siswa mengerjakan soal tersebut. Ketika siswa mengerjakan soal, guru memberikan bimbingan apabila ada siswa yang mengalami kesulitan. Pada akhir pembelajaran diadakan tes untuk mengetahui hasil belajar matematika materi menulis dan membaca bilangan bulat.

\section{Hasil Tes Siswa}

Pada akhir pembelajaran diadakan tes untuk mengetahui hasil belajar matematika materi membaca dan menulis bilangan bulat. Adapun hasil tes prasiklus dapat dilihat pada Tabel 4.1 berikut,

Tabel 4.1 Persentase Hasil Belajar Matematika pada Prasiklus

\begin{tabular}{|c|c|c|c|c|l|}
\hline No. & Nilai & Frekuensi & N X F & Persentase & \multicolumn{1}{|c|}{ Keterangan } \\
\hline 1 & 85 & 2 & 170 & 10,0 & Tuntas \\
\hline 2 & 80 & 0 & 0 & 0 & Tuntas \\
\hline 3 & 75 & 0 & 0 & 0 & Tuntas \\
\hline 4 & 70 & 3 & 210 & 15,0 & Tuntas \\
\hline 5 & 65 & 3 & 195 & 15,0 & Tuntas \\
\hline 6 & 60 & 3 & 180 & 15,0 & Tidak Tuntas \\
\hline 7 & 55 & 3 & 165 & 15,0 & Tidak Tuntas \\
\hline 8 & 50 & 2 & 100 & 10,0 & Tidak Tuntas \\
\hline 9 & 45 & 1 & 45 & 5,0 & Tidak Tuntas \\
\hline 10 & 40 & 3 & 120 & 15,0 & \\
\hline \multicolumn{7}{|c|}{ Jumlah } & 20 & 1.185 & 100 & \\
\hline
\end{tabular}

Berdasarkan data tersebut diketahui ada 8 siswa yang sudah tuntas dan 12 siswa yang belum tuntas dalam pembelajaran pada materi membaca dan menulis lambang bilangan bulat dengan persentase ketuntasan yaitu $40 \%$. Berdasarkan hasil tes tersebut disimpulkan bahwa pembelajaran yang telah dilaksanakan tidak berhasil (tidak tuntas) karena persentase ketuntasannya di bawah 65\%. Oleh karena itu, perlu dilakukan perbaikan pembelajaran pada materi menulis dan membaca bilangan bulat.

\section{Paparan Kegiatan dan Hasil Pelaksanaan Siklus I}

Tahap yang dilaksanakan pada siklus I ada empat, yaitu perencanaan, pelaksanaan tindakan, observasi, dan refleksi. Berikut uraian dari tahap-tahap tersebut:

Perencanaan Tindakan I. Pada kegiatan ini hal-hal yang dilakukan oleh peneliti sebagai berikut: a) Menyusun instrumen penelitian yaitu lembar observasi dan soal tes siklus I. b) Menyusun Rencana Pelaksanaan Pembelajaran siklus I.

\section{Pelaksanaan Tindakan I}

Siklus I dilaksanakan dalam dua kali pertemuan. Tindakan pada siklus I dilaksanakan pada hari Jum'at tanggal 9 September 2016 dan Sabtu tanggal 10 September 2016. Pada pertemuan ini dibahas materi penjumlahan bilangan bulat 
positif dengan positif dan penjumlahan bilangan bulat negatif dengan negatif. Pada tahap ini peneliti dibantu oleh seorang teman sejawat yang bertugas mengamati aktivitas peneliti sebagai guru pada kegiatan pembelajaran yang sedang berlangsung. Adapun kegiatan pembelajaran yang berlangsung pada siklus I adalah sebagai berikut:

\section{Pertemuan 1}

\section{Kegiatan Awal}

Pada kegiatan awal, peneliti sebagai guru membuka pembelajaran dengan mengucapkan salam kemudian meminta siswa berdoa, dan mengecek kehadiran siswa. Selanjutnya, peneliti memulai pembelajaran dengan mengingatkan siswa mengenai materi pada pertemuan sebelumnya yaitu membaca dan menulis bilangan bulat. Kemudian peneliti mengkondisikan siswa berdiskusi mengenai materi yang akan dipelajari, berikut dialognya:
Peneliti : "Anak-anak ibu guru menpunyai hutang Rp 150.000,00, dan ibu guru hutang lagi Rp75.000,00 Ayo siapa yang tahu berapa hutang ibu sekarang rupiah ?"
Siswa A : "Saya Bu."
Peneliti : "Berapa Nak banyak hutang saya?"
Siswa A : "Rp225.000,00 buah Bu."
Peneliti : "lya, pinter sekali.Dari mana kamu bisa mendapatkan $R p$ 225.000,00?"
Siswa A : "ya -150.000 ditambah $-75.000 \mathrm{Bu."}$
Peneliti : "lya pinter. Nah, anak-anak hari ini kita akan belajar tentang penjumlahan dan pengurangan bilangan bulat"

Selanjutnya peneliti mengkondisikan siswa untuk menemukan tujuan pembelajaran yang ingin dicapai dan memperkenalkan "media pohon matematika" kepada siswa.

\section{Kegiatan Inti}

Peneliti melakukan tanya jawab dengan siswa tentang cara menjumlahkan bilangan bulat positif dengan positif, dan positif dengan negatif. Berikut ini dialog antara peneliti dengan siswa:

Peneliti : "Anak-anak misalnya ada bilangan 152 ditambah (-47) Ayo, coba siapa yang tahu hasilnya berapa?"

Siswa B : "Saya Bu."

Peneliti : "Ayo nak coba ke depan dituliskan caranya di papan tulis!"

Siswa $B \quad$ : (mengerjakan di papan tulis)

Kemudian peneliti bersama siswa yang lain mengoreksi jawaban siswa tersebut. Selanjutnya peneliti mengelompokkan siswa secara berpasangan dengan teman sebangkunya. Kemudian peneliti membagikan media pohon matematika kepada masing-masing kelompok. Kemudian siswa diminta berdiskusi untuk menumbuhkan daun pada media pohon matematika. Pada saat pelaksanaan diskusi, peneliti berkeliling untuk mengamati kegiatan siswa dan membimbing siswa untuk memahami permasalahan pada ranting pohon. Selain itu, peneliti juga mengamati keaktifan siswa dalam kegiatan diskusi tersebut. Setelah diskusi selasai, siswa menukarkan pohon matematika yang mereka buat dengan kelompok lain. Selanjutnya, siswa dibimbing guru untuk memeriksa kebenaran jawaban yang dituliskan pada daun pohon matematika. Berikut ini salah salah satu pohon matematika yang dibuat oleh siswa. 


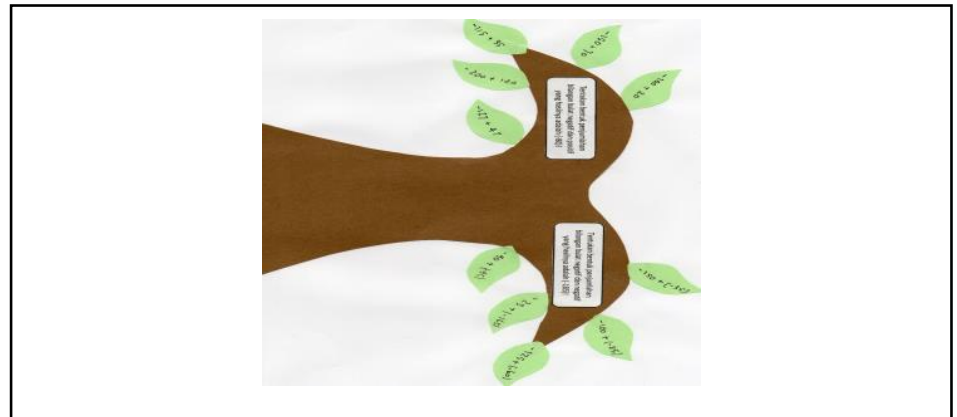

\section{Gambar 4.1 Pohon Matematika yang Dibuat Siswa pada Siklus I Pertemuan I Kegiatan Akhir}

Pada tahap ini, siswa mengumpulkan pohon matematika yang telah dibuat. Kemudian guru menginformasikan kegiatan pembelajaran pada pertemuan berikutnya yaitu penjumlahan bilangan bulat negatif dengan positif dan penjumlahan bilangan bulat negatif dengan negatif. Selanjutnya guru mengakhiri kegiatan pembelajaran dengan mengucapkan salam penutup.

\section{Pertemuan II \\ Kegiatan awal}

Pada tahap ini, peneliti sebagai guru membuka pembelajaran dengan mengucapkan salam kemudian meminta siswa berdoa, dan selanjutnya mengecek kehadiran siswa. Peneliti memulai pembelajaran dengan mengingatkan siswa mengenai kegiatan pada pertemuan sebelumnya yaitu penjumlahan bilangan bulat positif dengan positif dan positif dengan negatif. Kemudian peneliti menyampaikan kegiatan pembelajaran pada pertemuan kali ini yaitu penjumlahan bilangan bulat negatif dengan positif dan penjumlahan bilangan bulat negatif dengan negatif.

\section{Kegiatan Inti}

Pada kegiatan ini, siswa berkelompok secara berpasangan dengan teman sebangkunya sesuai dengan kelompok pada pertemuan sebelumnya. Peneliti memberikan media pohon matematika kepada setiap pasangan siswa. Kemudian, siswa menuliskan pasangan dua bilangan bulat negatif dan positif yang hasil penjumlahannya adalah $(-80)$ pada daun yang telah disediakan. Siswa menuliskan pasangan dua bilangan bulat negatif dan negatif yang hasil penjumlahannya adalah (185) pada daun yang telah disediakan. Selanjutnya, siswa menempelkan daun yang berisi pasangan bilangan bulat yang hasil penjumlahannya $(-80)$ dan $(-185)$ pada media pohon matematika. Setelah diskusi kelompok selesai, siswa dibimbing guru untuk memeriksa kebenaran jawabannya dengan cara saling menukar media pohon matematika dengan kelompok lain.

\section{Kegiatan Akhir}

Pada tahap ini, siswa bersama peneliti menyimpulkan materi pembelajaran pada pertemuan kali ini yaitu penjumlahan bilangan bulat. Peneliti juga memberikan kesempatan kepada siswa untuk menanyakan materi yang belum jelas, akan tetapi tidak ada siswa yang bertanya. Selanjutnya siswa diminta mengerjakan tes berupa lima soal uraian mengenai penjumlahan bilangan bulat secara perorangan. Setelah tes selesai, peneliti memberi tindak lanjut kepada siswa dengan memberikan pekerjaan rumah mengenai penjumlahan bilangan bulat. Selanjutnya peneliti mengakhiri kegiatan pembelajaran dengan mengucapkan salam.

\section{Observasi Tindakan I}

Observasi pada siklus I ini dilakukan selama pembelajaran berlangsung. Pada tahap observasi guru melakukan pengamatan terhadap siswa yang sedang belajar materi penjumlahan bilangan bulat dengan media pohon matematika sesuai dengan langkah-langkah pembelajaran RPP.

Hasil observasi kegiatan siswa selama diskusi kelompok berlangsung dapat dilihat pada Lampiran 4. Berdasarkan Lampiran 4 diketahui bahwa keantusiasan siswa 
kelas V SD Negeri 1 Tanggaran tergolong cukup baik yaitu sebesar 60\%. Siswa berkemampuan tinggi terlihat aktif dalam kegiatan diskusi, berani menyampaikan pendapat dan bertanya apabila mengalami kesulitan. Selain itu, mereka juga bekerjasama dengan baik dalam menumbuhkan daun pada pohon matematika. Siswa berkemampuan sedang juga terlihat bekerjasama dengan baik dan juga aktif dalam kegiatan diskusi. Keberanian menyampaikan pendapat siswa berkemampuan sedang juga mengalami peningkatan apabila dibandingkan pada pertemuan sebelumnya. Sebagai contoh, ada beberapa siswa berkemampuan sedang yang kadang-kadang menyampaikan pendapatnya ketika menumbuhkan daun pada pohon matematika. Sedangkan siswa berkemampuan rendah masih kurang antusias dalam kegiatan diskusi karena keberanian dan keaktifan mereka masih tergolong rendah. Siswa berkemampuan rendah cenderung diam dan juga masih ada yang berbicara dan bermain sendiri ketika kegiatan diskusi berlangsung.

\section{Refleksi Tindakan I}

Pada akhir pembelajaran siklus I diadakan tes untuk mengetahui hasil belajar matematika materi penjumlahan bilangan bulat. Adapun hasil tes tersebut dapat dilihat pada Tabel 4.2 berikut,

Tabel 4.2 Persentase Hasil Belajar Matematika pada Siklus 1

\begin{tabular}{|c|c|c|c|c|l|}
\hline No. & Nilai & Frekuensi & N X F & Persentase & \multicolumn{1}{|l|}{ Keterangan } \\
\hline 1 & 90 & 2 & 180 & 10,0 & Tuntas \\
\hline 2 & 80 & 3 & 240 & 15,0 & Tuntas \\
\hline 4 & 70 & 6 & 420 & 30,0 & Tuntas \\
\hline 6 & 60 & 5 & 300 & 25,0 & Tidak Tuntas \\
\hline 8 & 50 & 3 & 150 & 15,0 & Tidak Tuntas \\
\hline 10 & 40 & 1 & 40 & 5,0 & Tidak Tuntas \\
\hline \multicolumn{2}{|c|}{ Jumlah } & 20 & 1.330 & 100 & Tidak Tuntas \\
\hline \multicolumn{6}{|c|}{ Rata-rata } \\
\hline
\end{tabular}

Berdasarkan data tersebut diperoleh persentase ketuntasan adalah $55 \%$ atau sejumlah 11 siswa dari 20 siswa sudah mencapai ketuntasan. Sedangkan 9 siswa atau $45 \%$ dari 20 siswa masih belum tuntas pada materi penjumlahan bilangan bulat. Berdasarkan Tabel 4.1 persentase ketuntasan pada prasiklus adalah $40 \%$, sedangkan persentase ketuntasan pada siklus I adalah 55\%. Hal ini menunjukkan bahwa ada peningkatan antara prasiklus dengan tindakan siklus I sebanyak $15 \%$.

Berdasarkan paparan mengenai tindakan siklus I diketahui bahwa terjadi peningkatan pada hasil belajar matematika. Ada beberapa siswa yang pada prasiklus belum mencapai kriteria ketuntasan minimal, tetapi pada siklus I beberapa siswa tersebut sudah mencapai kriteria ketuntasan minimal. Siswa yang mencapai kriteria ketuntasan minimal sebanyak 11 siswa atau 55\%, padahal pada prasiklus hanya 8 siswa atau $40 \%$ yang mencapai kriteria ketuntasan minimal. Akan tetapi, hasil belajar matematika tersebut belum mencapai kriteria yang ditentukan yaitu siswa yang mencapai kriteria ketuntasan minimal belum mencapai 65\%. Oleh karena itu, perlu diadakan perbaikan tindakan pada siklus II.

Temuan-temuan pada waktu pelaksanaan tindakan siklus I adalah sebagai berikut: a) Ada beberapa siswa yang kurang semangat belajar, terlihat mengantuk, b) Ketika diskusi kelompok ada siswa yang hanya asyik bermain sendiri dan membiarkan teman yang lain mengerjakan tugas kelompoknya, c) Sebagian besar siswa masih terlihat kurang aktif ketika kegiatan tanya jawab, d) Ada empat kelompok yang mengalami kesulitan dalam menumbuhkan daun karena kebetulan anggota kelompoknya merupakan siswa golongan rendah semua, e) Persentase ketuntasan hasil belajar matematika mengalami peningkatan apabila dibandingkan dengan hasil belajar matematika pada prasiklus. Akan tetapi, banyaknya siswa yang mencapai kriteria ketuntasan minimal masih belum mencapai 65\%, yaitu masih 55\%.

Berdasarkan temuan tersebut, akan dilakukan perbaikan terhadap hal-hal yang belum dicapai di siklus I pada siklus II. 


\section{Paparan Kegiatan dan Hasil Pelaksanaan Siklus II}

Siklus II dilaksanakan pada hari Jum'at 16 September 2016 dan hari Sabtu tanggal 17 September 2016. Sama seperti pada siklus I, kegiatan yang dilaksanakan pada siklus II meliputi 4 tahap, yaitu perencanaan, pelaksanaan tindakan, observasi, dan refleksi. Berikut uraian dari masing-masing tahap tersebut.

\section{Perencanaan Tindakan II}

Berdasarkan permasalahan yang muncul pada siklus I, ada beberapa hal yang diharapkan tercapai pada siklus II, yaitu: a) Semua siswa bersemangat dalam kegiatan pembelajaran, b) Siswa dapat memahami setiap permasalahan yang diberikan, c) Siswa aktif dalam kegiatan tanya jawab, d) Persentase ketuntasan hasil belajar matematika mencapai 65\%.

Adapun hal-hal yang dilakukan oleh peneliti untuk mewujudkan target-target tersebut adalah sebagai berikut: a) Memperbaiki RPP berdasarkan hasil observasi siklus I, terutama pada kegiatan apersepsi yaitu dengan mengajak siswa bernyanyi bersama agar siswa lebih bersemangat, b) Merevisi Lembar Kegiatan Siswa (LKS) dengan membuatnya seperti komik yang mudah dipahami dan agar siswa lebih tertarik, c) Membentuk 5 kelompok kecil yang beranggotakan 4 siswa secara heterogen.

\section{Pelaksanaan Tindakan II}

Siklus ini dilaksanakan dalam dua kali pertemuan. Tindakan pada siklus II dilaksanakan pada tanggal 16 September 2016 dan 17 September 2016. Pada pertemuan ini dibahas materi pengurangan bilangan bulat. Adapun kegiatan pembelajaran yang berlangsung pada siklus II adalah sebagai berikut:

\section{Kegiatan Awal}

Pada kegiatan awal, peneliti sebagai guru membuka pembelajaran dengan mengucapkan salam kemudian meminta siswa berdoa, dan mengecek kehadiran siswa. Selanjutnya, peneliti mengingatkan siswa kepada materi pada pertemuan sebelumnya yaitu penjumlahan bilanngan bulat.

Selanjutnya peneliti mengkondisikan siswa untuk menemukan tujuan pembelajaran yang ingin dicapai yaitu melalui diskusi kelompok siswa dapat mengurangkan bilangan bulat. Kemudian peneliti memperkenalkan "media pohon matematika" kepada siswa dan cara menggunakan media tersebut.

\section{Kegiatan Inti}

Peneliti melakukan tanya jawab dengan siswa tentang cara mengurangkan bilangan bulat. Berikut ini dialog antara peneliti dengan siswa:

Peneliti : "Anak-anak misalnya bu guru mempunyai uang Rp 5.000,00 kemudian uang tersebut yang $R p$ 3.000,00 bu guru gunakan untuk membeli penghapus. Coba anak-anak kalian hitung berapa uang bu guru sekarang! Ayo siapa yang bisa silahkan angkat tangan!"

Siswa E : "Saya Bu."

Peneliti : "Berapa uang ibu sekarang nak?"

Siswa E : "Rp2.000,00 Bu"

Peneliti : "lya pinter nak"

Peneliti : :Sekarang bu guru mempunyai hutang Rp7.000,00, kemudian bu guru membayarnya dengan uang sepuluh ribuan.Coba anakanak kalian hitung berapa rupiah pengembaliannya! Ayo siapa

Siswa $F$ yang sudah menemukan!

Peneliti : "Ayo ditulis di papan tulis nak, bagaimana caranya!"

Siswa $F \quad$ : (mengerjakan di papan tulis).

Kemudian peneliti bersama siswa yang lain mengoreksi jawaban siswa tersebut. Selanjutnya peneliti mengelompokkan siswa menjadi 5 kelompok kecil yang 
beranggotakan 4 siswa secara heterogen. Kemudian peneliti membagikan Lembar Kegiatan Siswa (LKS) dan media pohon matematika kepada masing-masing kelompok. Kemudian siswa diminta berdiskusi untuk menumbuhkan daun pada media pohon matematika berdasarkan petunjuk di Lembar Kegiatan Siswa (LKS) yaitu menuliskan pasangan dua bilangan bulat positif dan positif yang hasil pengurangannya adalah 243 pada daun yang telah disediakan. Selain itu, siswa menuliskan pasangan dua bilangan bulat positif dan negatif yang hasil pengurangannya adalah ( -96) pada daun yang telah disediakan. Selanjutnya, siswa menempelkan daun yang berisi pasangan bilangan bulat yang hasil pengurangannya 243 dan (- 96) pada media pohon matematika. Pada saat pelaksanaan diskusi, peneliti berkeliling untuk mengamati kegiatan siswa dan membimbing siswa untuk memahami permasalahan pada Lembar Kegiatan Siswa (LKS) dengan memberikan pertanyaan pancingan. Selain itu, peneliti juga mengamati keaktifan siswa dalam kegiatan diskusi tersebut. Setelah diskusi selasai, siswa dibimbing guru untuk memeriksa kebenaran jawaban yang dituliskan pada daun pohon matematika. Berikut salah satu hasil pohon matematika Kelompok 1.

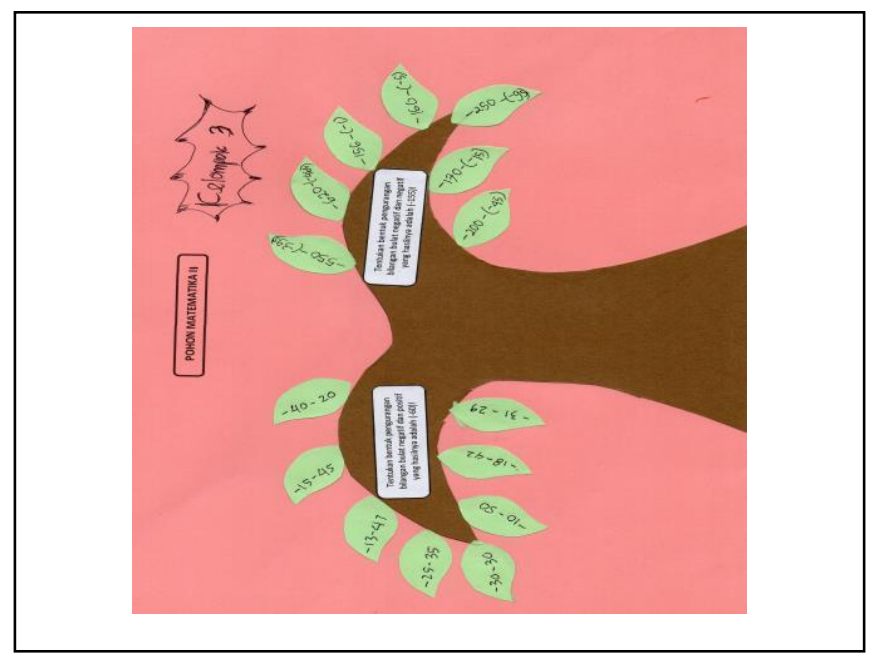

\section{Gambar 4.2 Pohon Matematika Kelompok 1 pada Siklus II}

\section{Kegiatan Akhir}

Pada tahap ini, siswa mengumpulkan pohon matematika pengurangan I yang telah dibuat. Kemudian guru menginformasikan kegiatan pembelajaran pada pertemuan berikutnya yaitu pengurangan bilangan bulat negatif dengan positif dan pengurangan bilangan bulat negatif dengan negatif. Selanjutnya guru mengakhiri kegiatan pembelajaran dengan mengucapkan salam penutup.

\section{Pertemuan 2 Kegiatan Awal}

Pada tahap ini, peneliti sebagai guru membuka pembelajaran dengan mengucapkan salam kemudian meminta siswa berdoa, dan selanjutnya mengecek kehadiran siswa. Peneliti memulai pembelajaran dengan mengingatkan siswa mengenai kegiatan pada pertemuan sebelumnya yaitu pengurangan bilangan bulat positif dengan positif dan positif dengan negatif. Kemudian peneliti menyampaikan kegiatan pembelajaran pada pertemuan kali ini yaitu pengurangan bilangan bulat negatif dengan positif dan pengurangan bilangan bulat negatif dengan negatif.

\section{Kegiatan Inti}

Pada kegiatan ini, siswa berkelompok secara berpasangan sesuai dengan kelompok pada pertemuan sebelumnya. Peneliti memberikan media pohon matematika kepada setiap kelompok. Kemudian, siswa menuliskan pasangan dua bilangan bulat negatif dan positif yang hasil pengurangannya adalah (-60) pada daun yang telah 
disediakan. Siswa menuliskan pasangan dua bilangan bulat negatif dan negatif yang hasil pengurangannya adalah (-155) pada daun yang telah disediakan. Selanjutnya, siswa menempelkan daun yang berisi pasangan bilangan bulat yang hasil pengurangannya $(-60)$ dan $(-155)$ pada media pohon matematika. Setelah diskusi kelompok selesai, siswa dibimbing guru untuk memeriksa kebenaran jawabannya dengan cara saling menukar media pohon matematika dengan kelompok lain.

\section{Kegiatan Akhir}

Pada tahap ini, siswa bersama peneliti menyimpulkan materi pembelajaran pada pertemuan kali ini yaitu pengurangan bilangan bulat. Peneliti juga memberikan kesempatan kepada siswa untuk menanyakan materi yang belum jelas, akan tetapi tidak ada siswa yang bertanya. Selanjutnya siswa diminta mengerjakan tes berupa lima soal uraian mengenai pengurangan bilangan bulat secara perorangan. Setelah tes selesai, peneliti memberi tindak lanjut kepada siswa dengan memberikan pekerjaan rumah mengenai pengurangan bilangan bulat. Selanjutnya peneliti mengakhiri kegiatan pembelajaran dengan mengucapkan salam.

\section{Observasi Tindakan II}

Observasi pada siklus II ini dilakukan selama pembelajaran berlangsung. Hasil observasi kegiatan siswa selama diskusi kelompok berlangsung dapat dilihat pada Lampiran 6. Berdasarkan data yang diperoleh diketahui bahwa keantusiasan siswa kelas V SD Negeri 1 Tanggaran tergolong baik yaitu sebesar $80 \%$ sehingga mengalami peningkatan apabila dibandingkan pada siklus I. Siswa berkemampuan tinggi terlihat aktif dalam kegiatan diskusi, berani menyampaikan pendapat dan bertanya apabila mengalami kesulitan, serta bekerjasama dengan baik dalam menyelesaikan permasalahan mengenai penjumlahan dan pengurangan bilangan bulat. Siswa berkemampuan sedang juga terlihat bekerjasama dengan baik dan juga aktif dalam kegiatan diskusi meskipun tidak seaktif siswa berkemampuan tinggi. Keberanian menyampaikan pendapat siswa berkemampuan sedang juga mengalami peningkatan apabila dibandingkan pada pertemuan sebelumnya. Mereka lebih sering menyampaikan pendapat ketika menyelesaikan permalasahan mengenai pengurangan bilangan bulat jika dibandingkan dengan pertemuan sebelumnya. Siswa berkemampuan rendah lebih antusias dalam kegiatan diskusi daripada siklus I. Ada beberapa siswa yang menyampaikan pendapatnya dalam menumbuhkan daun pohon matematika. Namun, masih ada siswa yang terkadang bermain sendiri ketika diskusi berlangsung.

\section{Refleksi Tindakan II}

Pada akhir pembelajaran siklus II diadakan tes untuk mengetahui hasil belajar matematika. Adapun hasil tes tersebut dapat dilihat pada Tabel 4.3 berikut ini,

Tabel 4.3 Persentase Hasil Belajar Matematika pada Siklus II

\begin{tabular}{|c|c|c|c|c|l|}
\hline No. & Nilai & Frekuensi & N X F & Persentase & \multicolumn{1}{|c|}{ Keterangan } \\
\hline 1 & 100 & 2 & 200 & 10,0 & Tuntas \\
\hline 2 & 90 & 2 & 180 & 10,0 & Tuntas \\
\hline 3 & 80 & 3 & 240 & 15,0 & Tuntas \\
\hline 4 & 70 & 8 & 560 & 40,0 & Tuntas \\
\hline 5 & 60 & 3 & 180 & 15,0 & Tidak Tuntas \\
\hline 6 & 50 & 2 & 100 & 10,0 & Tidak Tuntas \\
\hline \multicolumn{2}{|c|}{ Jumlah } & 20 & 1.460 & 100 & Tidak Tuntas \\
\hline \multicolumn{6}{|c|}{ Rata-rata } \\
\hline
\end{tabular}

Berdasarkan data tersebut diperoleh persentase ketuntasan adalah $75 \%$ atau sejumlah 15 siswa dari 20 siswa sudah mencapai ketuntasan. Sedangkan 5 siswa atau $25 \%$ dari 20 siswa masih belum tuntas pada materi pengurangan bilangan bulat. Berdasarkan Tabel 4.2, persentase ketuntasan pada siklus I adalah 55\%, sedangkan persentase ketuntasan pada siklus II adalah 75\%. Hal ini menunjukkan bahwa ada peningkatan dari tindakan siklus I dengan tindakan siklus II sebanyak $20 \%$. 
Berdasarkan paparan mengenai tindakan pada siklus II terjadi peningkatan pada hasil belajar matematika dimana hampir semua siswa pada siklus II telah mencapai kriteria ketuntasan minimal. Jumlah siswa yang mencapai nilai ketuntasan minimal adalah 15 siswa atau $75 \%$, sehingga terjadi peningkatan sebesar $20 \%$ jika dibandingkan siklus I. Berdasarkan observasi pada siklus II, banyaknya siswa yang telah mencapai kriteria ketuntasan minimal lebih dari $65 \%$. Oleh karena itu, pembelajaran pada siklus ini dinyatakan berhasil.

Adapun temuan-temuan pada waktu pelaksanaan tindakan pada siklus II antara lain: a) Penerapan media pohon matematika untuk meningkatkan hasil belajar matematika pada materi penjumlahan dan pengurangan bilangan bulat di kelas V SD Negeri 1 Tanggaran sudah berjalan dengan baik, b) Hasil belajar matematika mengalami peningkatan yang signifikan, c. Keaktifan siswa dalam kegiatan tanya jawab masih perlu ditingkatkan lagi, terutama bagi siswa yang berkemampuan rendah.

\section{Paparan Perbandingan Hasil Siklus I dan Siklus II}

Sebelum dilakukan tindakan perbaikan, hasil belajar matematika materi penjumlahan dan pengurangan bilangan bulat pada siswa kelas $\mathrm{V}$ SD Negeri 1 Tanggaran sebagian besar masih belum memenuhi kriteria ketuntasan minimal (KKM). Berdasarkan Tabel 4.1 diketahui bahwa nilai rata-rata kelas untuk materi penjumlahan bilangan bulat adalah 59,25. Selain itu, dari Tabel 4.1 diperoleh dari 20 siswa kelas $\mathrm{V}$ SD Negeri 1 Tanggaran terdapat 12 siswa (60\%) yang hasil belajarnya tidak mencapai kriteria ketuntasan minimal, dan 8 siswa (40\%) yang mampu mencapai nilai ketuntasan minimal. Oleh sebab itu, perlu dilakukan perbaikan pembelajaran pada materi penjumlahan dan pengurangan bilangan bulat agar hasil belajar matematika dapat meningkat dan mencapai kriteria ketuntasan minimal.

Setelah diterapkan media pohon matematika pada pembelajaran materi penjumlahan dan pengurangan bilangan bulat, terjadi peningkatan hasil belajar matematika. Berdasarkan Tabel 4.2, diperoleh bahwa nilai rata-rata kelas adalah 66,50. Berdasarkan Tabel 4.2 juga diketahui bahwa dari 20 siswa terdapat 11 siswa atau $55 \%$ siswa yang mampu mendapatkan nilai di atas kriteria ketuntasan minimal, sedangkan 9 siswa atau 45\% siswa masih belum mencapai kriteria kentuntasan minimal. Sehingga kelas V SD Negeri 1 Tanggaran belum mencapai kriteria ketuntasan minimal kelas yaitu 65. Oleh karena itu, pelaksanaan pembelajaran masih perlu perbaikan lagi agar hasil belajar siswa lebih meningkat.

Pada siklus II juga terjadi peningkatan hasil belajar. Hal ini sesuai dengan hasil penelitian yang dilakukan oleh Rosnin dan Dahlan (2010) diperoleh bahwa penggunaan media pohon matematika dapat meningkatkan hasil belajar sifat-sifat bangun datar siswa kelas V SDN No. 02 Dompu. Berdasarkan Tabel 4.3 diketahui bahwa nilai rata-rata hasil belajar matematika adalah 73,00. Selain itu, dari Tabel 4.3 diketahui bahwa persentase ketuntasan pada siklus II adalah $75 \%$ atau sebanyak 15 siswa dari 20 siswa sudah mencapai kriteria ketuntasan minimal. Sedangkan 5 siswa atau $25 \%$ dari 20 siswa masih belum tuntas dalam pembelajaran pada materi penjumlahan dan pengurangan bilangan bulat. Nilai ketuntasan pada siklus I adalah $55 \%$, sedangkan nilai ketuntasan pada siklus II adalah $75 \%$. Hal ini menunjukkan bahwa ada peningkatan dari tindakan siklus I dengan tindakan siklus II sebanyak $20 \%$. Berdasarkan observasi pada siklus II, banyaknya siswa yang telah mencapai kriteria ketuntasan minimal lebih dari $65 \%$. Oleh karena itu, pembelajaran pada siklus ini telah berhasil. Selain itu, dapat dikatakan bahwa hasil belajar matematika pada siklus II sudah mengalami peningkatan yang signifikan. Peningkatan hasil belajar tersebut salah satunya disebabkan siswa lebih mudah memahami konsep penjumlahan dan pengurangan bilangan cacah karena melalui media pohon matematika siswa dapat mengembangkan penalaran tentang penjumlahan dan pengurangan bilangan cacah. Hal ini sesuai dengan pendapat Subanji (2011) bahwa pohon matematika merupakan suatu media yang dapat digunakan untuk mengembangkan penalaran siswa. 
Adapun grafik peningkatan hasil belajar matematika materi penjumlahan dan pengurangan bilangan bulat pada siswa kelas V SD Negeri 1 Tanggaran semester 1 tahun pelajaran 2018/2019 dapat dilihat pada Gambar 4.1 berikut,

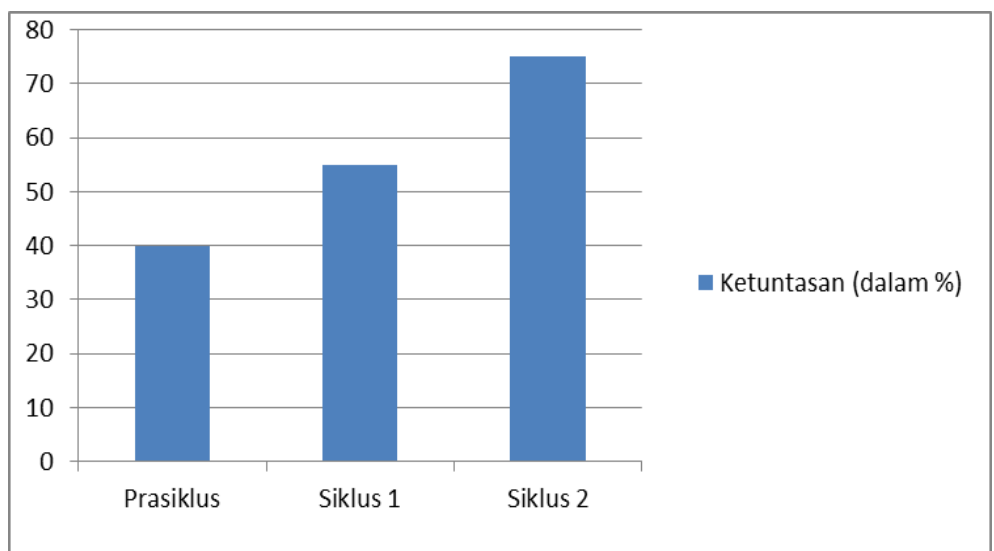

Gambar 4.3 Grafik Hasil Belajar Matematika Materi Penjumlahan dan Pengurangan Bilangan Bulat pada Siswa Kelas V SDN 1 Tanggaran

\section{KESIMPULAN}

Berdasarkan penelitian yang telah dilakukan dan pembahasan pada bab sebelumnya, maka dapat ditarik kesimpulan bahwa media pohon matematika dapat meningkatkan hasil belajar matematika materi penjumlahan dan pengurangan bilangan bulat pada siswa kelas V SD Negeri 1 Tanggaran semester 1 tahun pelajaran 2018/2019. Hal ini dapat dilihat dari nilai rata-rata tes siswa berturut-turut pada pra siklus, siklus I, dan siklus II yang meningkat, yaitu 59,25, 66,50 dan 73,00. Selain itu, ketuntasan belajar pada prasiklus, siklus I, dan siklus II juga meningkat yaitu $40 \%$ (tidak tuntas), 55\% (tidak tuntas) dan 75\% (tuntas).

\section{DAFTAR RUJUKAN}

Hudojo, Herman. 2005. Pengembangan Kurikulum dan Pembelajaran Matematika. Malang: JICA.

Kholili, Bahtiar. 2012. Penelitian Tindakan Kelas Mudah \& Berkualitas. Trenggalek.

Moleong, J. Lexy. 2011. Metodologi Penelitian Kualitatif. Bandung: PT Remaja Rosdakarya.

Muhsetyo, Gatot. 2009. Pembelajaran Matematika SD. Jakarta: Universitas Terbuka.

Mulyasa. 2007. Kurikulum Berbasis Kompetensi: Konsep, Karakteristik dan Penerapannya dalam KBK. Bandung: Remaja Rosdakaya.

Rosnin dan Dahlan. 2010. Penggunaan Media Pohon Matematika untuk Meningkatkan Hasil Belajar. JTQIP, 1(1): 101-103.

Subanji. 2011. Pembelajaran Matematika Kreatif dan Inovatif. Malang: UM Press.

Suherman, Erman. 2001. Strategi Pembelajaran Matematika Kontemporer. Malang: JICA.

Sumanto. 2012. Media Pembelajaran SD. Malang: UM-PSG Rayon 15.

Wardani, I G. A. K. 2013. Pemantapan Kemampuan Profesional. Tangerang: Universitas Terbuka.

Wicaksono, A. 2014. Menulis Kreatif Sastra dan Beberapa Model Pembelajarannya. Yogyakarta: Garudhawaca. 